\title{
THE TAMBOS OF THE PERUVIAN RURAL TERRITORY: A SYSTEMATIC CATALOG PROPOSAL AS DESIGN STRATEGY
}

\author{
Cristian YARASCA-AYBAR (1D) 1,2, \\ ${ }^{1}$ Maestría en Arquitectura y Procesos Proyectuales, Pontificia Universidad Católica del Perú, Lima, Perú \\ ${ }^{2}$ Escuela Profesional de Arquitectura, Universidad Peruana Unión, Lima, Perú
}

Received 04 December 2020; accepted 22 April 2021

\begin{abstract}
The tambos are small buildings that function as social platforms in Peruvian rural areas to provide essential services to the entire vulnerable and dispersed rural population. The Peruvian government intends to implement more than a thousand new tambos in the national territory. However, this social infrastructure program faces heterogeneous conditions and demands according to Peru's geographical and population complexity. This article proposes developing a systematic catalog of modular components as a design strategy for the architectural approach of future tambos. Georeferenced data and climate design guidelines were used to conduct this study. As a result, the systematic catalog synthesizes critical variables such as natural regions and programmatic requirements to generate diverse architectural configurations of the new tambos. Therefore, these future buildings would be optimally articulated in different areas of influence under a systematic vision of the Peruvian rural territory.
\end{abstract}

Keywords: architectural design, design strategy, sustainability, rural, problem solving.

\section{Introduction}

In 2014, the Peruvian government created the "National Program of Tambos" (NPT) intending to fight poverty in the most remote rural areas of the national territory $(\mathrm{Li}$ Liza, 2016, p. 34). The NPT aims to provide access to social services to the rural population centers with the highest incidence of poverty and high population dispersion to contribute to their economic, social and productive development (Ministerio de Desarrollo e Inclusión Social [MIDIS], 2017, p. 3). To achieve this, the NPT implemented the tambos, which are small buildings (Figure 1) that function as the physical platform where the different public and private institutions can offer their social services to the Peruvian rural population. This functional quality of the tambos is called multi-sectorial because it promotes territorial development by recognizing that the rural territory is made up of diverse actors and small locations (Kámiche, 2015, p. 12). For this reason, in these years of existence, the tambos have become the physical environment (building) to integrate and strengthen public and private actor's interventions ${ }^{1}$ for

\footnotetext{
1 Some of the important institutions of the Peruvian government that use the tambos are the Ministry of Development
}

the benefit of the vulnerable population of the Peruvian rural area.

The "National Program of Tambos" (NPT) has built, up to now, around 514 tambos in the national territory. It has the objective of building a total of 1600 tambos in the long term to cover the entire target population of around 5 million Peruvians in the rural sector in conditions of poverty (Preissing et al., 2016, p. 46). The current tambos are exposed to different geographical and population dynamics that correspond to the heterogeneity of the rural population centers. Likewise, future tambos will have to be located in other rural population centers where the physical and demographic conditions are still uncertain due to the planning of the Peruvian government, the remoteness of the location areas, and the geographical complexity of the territory that comprises the Peruvian rurality.

The tambos show that the rural territory, often considered a sterile space for architecture, is an opportune territory for planning operations. Thus, the discipline of

and Social Inclusion (MIDIS), the National Registry of Identity and Civil Status (RENIEC) with access to the national identity card, and the Ministry of Agriculture and Irrigation (MINAGRI) promoting agricultural production.

*Corresponding author. E-mail: cristianyarasca@upeu.edu.pe 

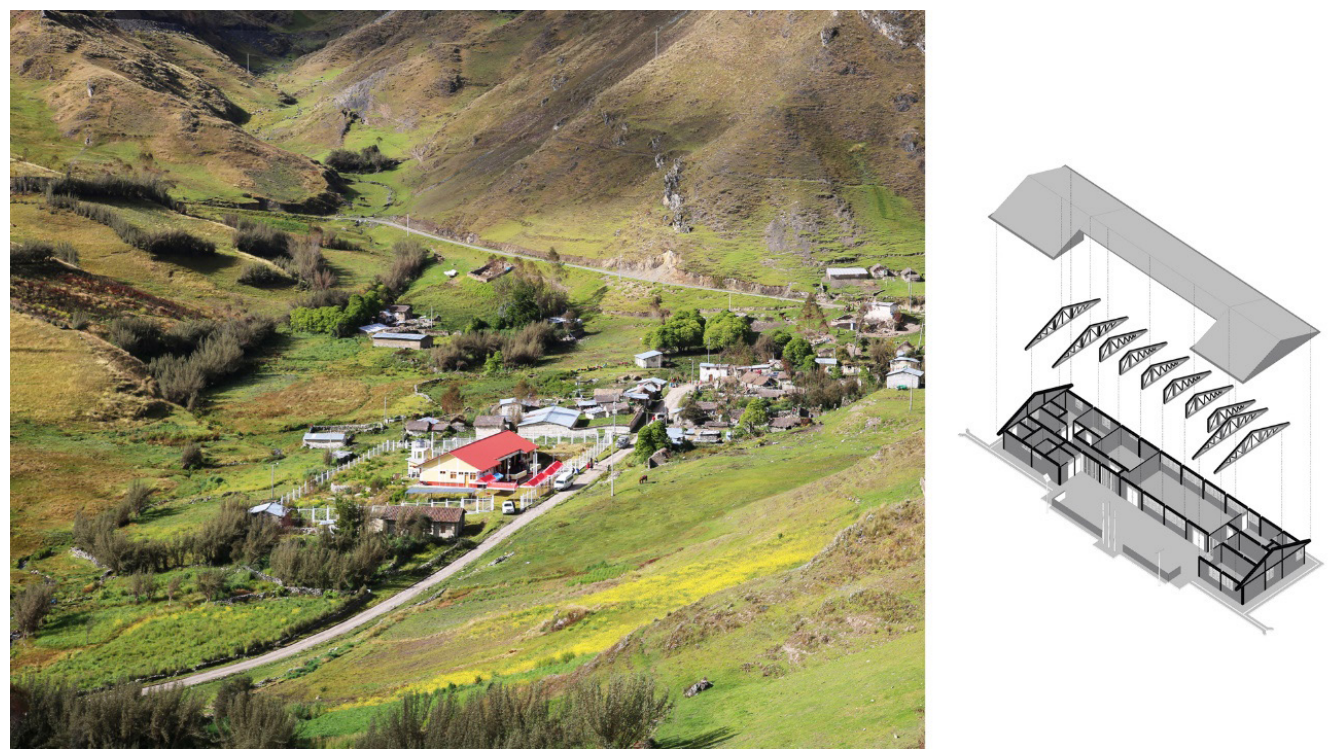

Figure 1. Tambo in Ayacucho, Peru (left). Exploded axonometric of a typical Tambo (right) (source: MIDIS, 2014)

architecture should play a preponderant role in optimally implementing future tambos. This premise generates the following research question: What will be the design strategy to be followed by the "National Program of Tambos" to articulate the architectural design of future tambos to the particular conditions of their respective areas of influence?

Therefore, the objective of this research is to propose a systematic catalog of modular components for the implementation of the new tambos in order to articulate these buildings to the complexity of the national territory by adapting the physical form and architectural program of the tambos to the geographic-population conditions and the productive capacity of their respective rural populated centers.

\section{Population dispersion and access to essential services}

In Peru, the technical definition of the rural area was historically governed by census purposes. Since 1940, an apparent dichotomy was established that relegated the description ${ }^{2}$ of rurality to what "was not city or urban" (Dirven, 2019, p. 18). At that time, the definition of the rural area was residual and in contrast to the various definitions of the urban area (Remy, 2009, p. 1); causing a historical underestimation of the countryside (Puente, 2019) by the national government's public policies (Dirven et al., 2011, p. 22). It is only since 2007 that the rural sector has received its definition by the Peruvian government under

\footnotetext{
2 In the national censuses of 1940 and 1961, the rural was defined as "the rest of the population centers without urban characteristics"; later, in 1972, 1981, 1993, the rural was considered "that were not agglomerations of more than 100 contiguous houses".
}

a quantitative aspect: "areas where less than 2 thousand inhabitants or 500 families live" (Instituto Nacional de Estadística e Informática [INEI], 2017, p. 30). These historical antecedents force us to question whether this conceptual border between both worlds still exists today or is fading away. Therefore, the urban and rural would conform a territorial "continuum" (Di Liscia, 2017, p. 164) with some socio-spatial nuances (Branca, 2019, p. 20), more than two antagonistic ${ }^{3}$ fronts.

In Peru, any place in the national territory, rural or urban, identified by a name and inhabited with permanence, is called "populated center". Whether urban or rural, the populated centers are classified (Table 1) according to the amount of population they house: Dispersed, Hamlet, Village, Town, City, and Metropolis (Kámiche, 2015, p. 20). It is known that the most significant percentage of the Peruvian population lives in populated urban centers; however, the number of populated rural centers (97 277) is much higher than the populated urban centers (734). It means more than $99 \%$ of Peru's populated centers are in the rural sector, and less than $1 \%$ represent the urban sector, even though urban centers are home to more than $70 \%$ of Peru's total population. This phenomenon is called "population dispersion"; which means that few people live in many populated centers that are often very far from each other (population density less than 15 Inhabitants per square kilometer).

\footnotetext{
3 For example, the OECD defines rural as having a population density of fewer than 150 inhabitants $/ \mathrm{km}^{2}$ and a distance to urban areas of more than one hour (de Ferranti et al., 2005, p. 46).
} 
Table 1. Categories and quantity of populated centers in Peru

\begin{tabular}{|c|c|c|c|c|c|c|}
\hline Area & Population Range & $\begin{array}{l}\text { Populated } \\
\text { Centers } \\
\text { Categories }\end{array}$ & Quantity & Percentage & $\begin{array}{c}\text { Quantity } \\
\text { Population }\end{array}$ & $\begin{array}{l}\text { Percentage } \\
\text { Population }\end{array}$ \\
\hline \multirow[t]{3}{*}{ Rural Area } & $1-150$ & Dispersed & 80976 & $82.6 \%$ & 2480926 & $9.1 \%$ \\
\hline & $151-1000$ & Hamlet & 15640 & $16.0 \%$ & 4850862 & $17.7 \%$ \\
\hline & $1001-2000$ & Village & 661 & $0.7 \%$ & 896927 & $3.3 \%$ \\
\hline \multirow[t]{4}{*}{ Urban Area } & $2001-5000$ & Town & 365 & $0.4 \%$ & 1111444 & $4.1 \%$ \\
\hline & $5000-500000$ & City & 367 & $0.4 \%$ & 16593994 & $60.5 \%$ \\
\hline & More than 500000 & Metropolis & 2 & $0.0 \%$ & 1478004 & $5.4 \%$ \\
\hline & & & 98011 & $100.0 \%$ & $27412 \quad 157$ & $100.0 \%$ \\
\hline
\end{tabular}

Note: Data are from Kámiche (2015, p. 20).

The most significant concentration of populated centers in Peru is in the high Andean zone ${ }^{4}$, which unfortunately coincides with the highest national poverty (Figure 2). It is estimated that $58 \%$ of Peru's rural population is in a condition of poverty (Kámiche, 2015, p. 7) and with limited access to essential services such as electric power, civil identification, telecommunications, health, education; causing different damages to the productivity and well-being ${ }^{5}$ of the people. Although the Peruvian territory has a complex ${ }^{6}$ and heterogeneous geographical distribution (Escobal D’Angelo \& Torero, 2000, p. 1), why do people in remote territories suffer from so many basic needs? A tentative answer to this question is the high costs of accessibility ${ }^{7}$ due to the rugged geography (Zavaleta, 2016 , p. 18). To this is added the population dispersion that increases the difficulty for the Peruvian government to provide essential services. Consequently, the lack of essential services for the rural population has consequences for society as a whole (urban and rural). This link between both areas is evidenced by the fact that the amount of the rural population in each Peru department is a direct reflection of its overall poverty incidence.

The lastest economic dynamics in the rural sector (Morley, 2017), accompanied by national and international efforts ${ }^{8}$, have sought to generate higher rural produc-

4 The high Andean zone formed by the "Cordillera de los Andes" represents $31 \%$ of the national territory.

5 One of the biggest problems in the area of health is chronic malnutrition (Eguren, 2016, p. 92).

6 Peru is located in the tropical zone of the planet. However, mainly due to the variations in relief (altitude) by the Andes, there is a multitude of microclimates (more than 28) that condition the use of land and agricultural activities of the country (Ministerio del Ambiente [MINAM], 2019).

7 In rural Peru, some communities can only be reached by walking for hours or by boat trips on rivers that can even last for days (Zavaleta, 2016, p. 18).

8 At the national level, the law of "Promotion for the Development of Productive Activities in High Andean Areas" (Min- tivity and reduce socio-economic vulnerability (Haudry de Soucy, 2013, p. 2). These efforts have had a positive effect in recent decades (Flachsbarth et al., 2018). In this context, the Peruvian government created the "National Program of Tambos" (NPT) to provide essential services to the rural poor through actions with a territorial vision. In this way, the NPT articulates multi-sectoral services as part of a national strategy to reduce rural poverty that is multidimensional $^{9}$ (Preissing et al., 2016, pp. 30-37). Therefore, the location of the 514 current tambos (Figure 3) represents the active physical presence of the Peruvian government because it manages to reach different points of the national territory (most of tambos are found in the highest altitude areas), overcoming the logistical and communicational challenge that the Peruvian geography represents.

Likewise, the tambos have a built area of approximately 300 square meters and their location is planned through location rules based on the logic of distance, connectivity, and areas of influence (Figure 4). For this reason, these buildings have managed to settle in strategic locations of the Peruvian territory, and this has resulted in the direct influence of the tambos reaching to benefit more than 1 million inhabitants of the rural areas. These areas have a higher incidence of poverty and, at the same time, have different social, cultural, and economic characteristics population (Figure 5) (Chumacero, 2015).

isterio de Economía y Finanzas [MEF], 2010) establishes tax exemptions above 2500 (masl) in order to promote productivity in specific activities (agro-industry, aquaculture, fish farming, dairy, forest plantations, meat, camelid breeding and fiber, handicrafts and textiles). Likewise, the "International Fund for Agricultural Development" (IFAD) is an international organization that has an essential presence in the Peruvian rural area and operates mainly in the northern and southern sierra.

9 By multidimensional, it means that poverty is not only monetary. Thus, the National Program of Tambos intervenes in human capital, social capital, environmental capital, financial capital, and business capital (Preissing et al., 2016, p. 30). 

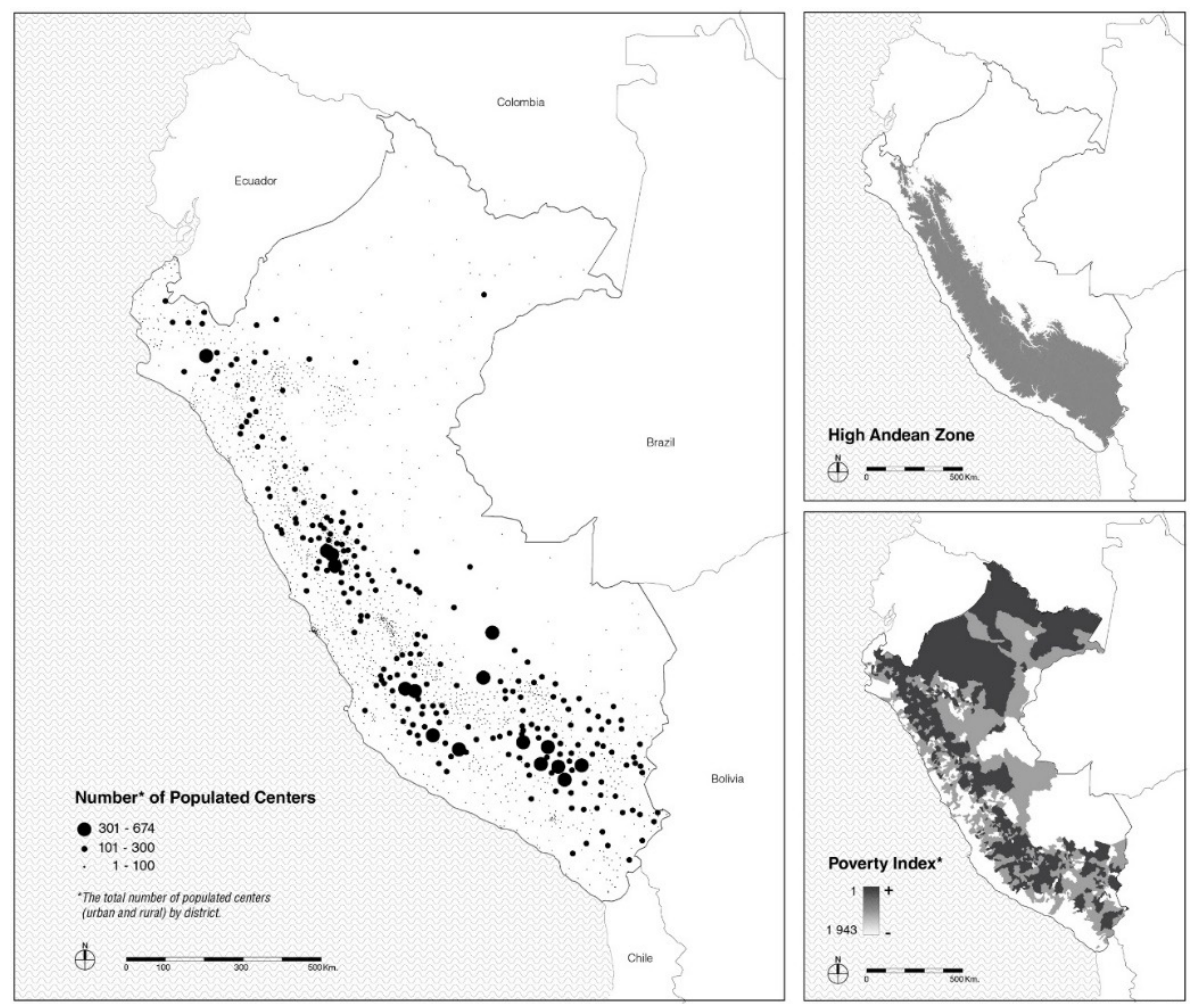

Figure 2. The concentration of populated centers and the incidence of poverty (source: author, elaboration with data from INEI (2018a, 2018b)
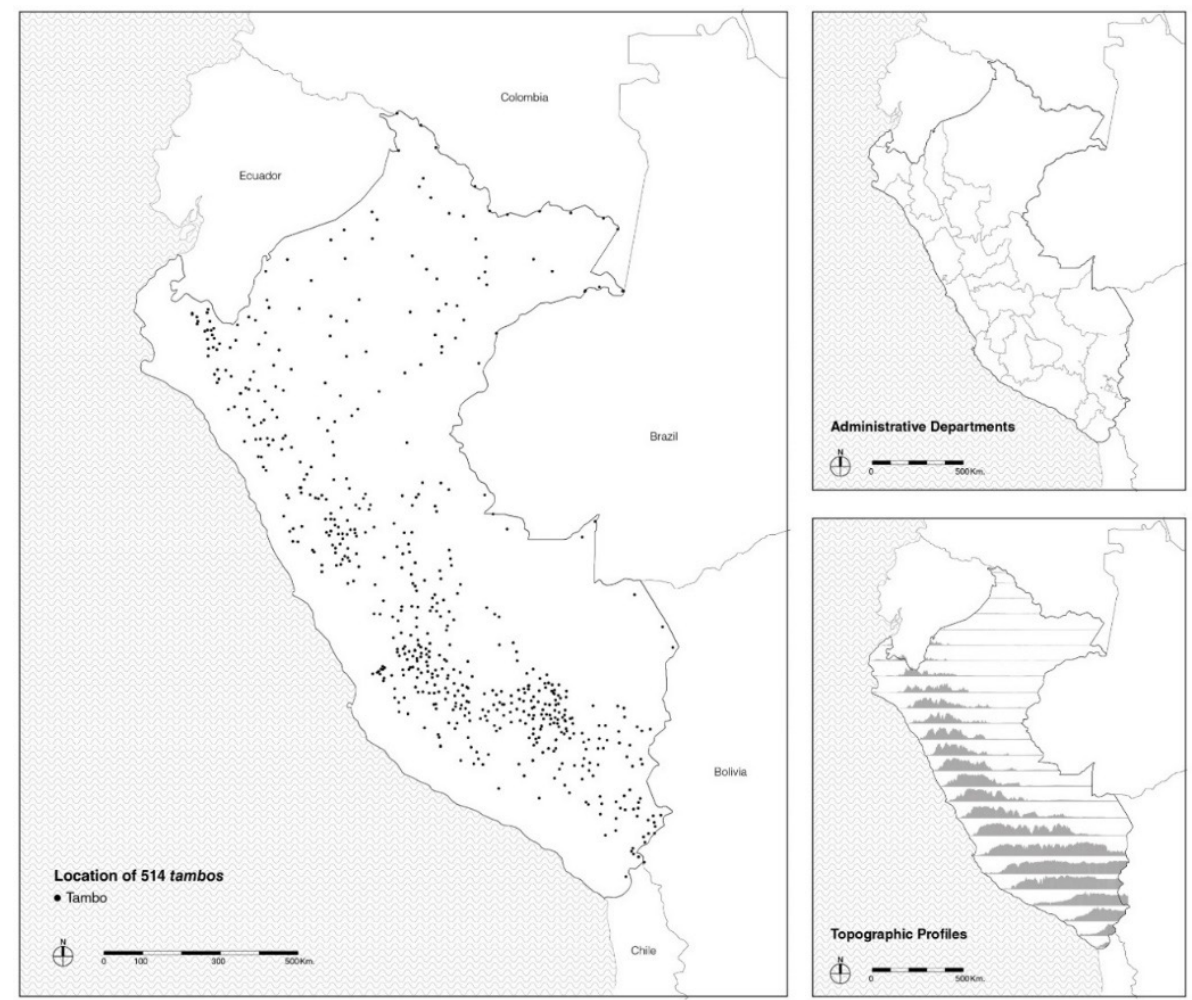

Figure 3. Location of the current 514 "tambos" in the Peruvian territory (source: author, elaboration with data from Tambook, 2017) 


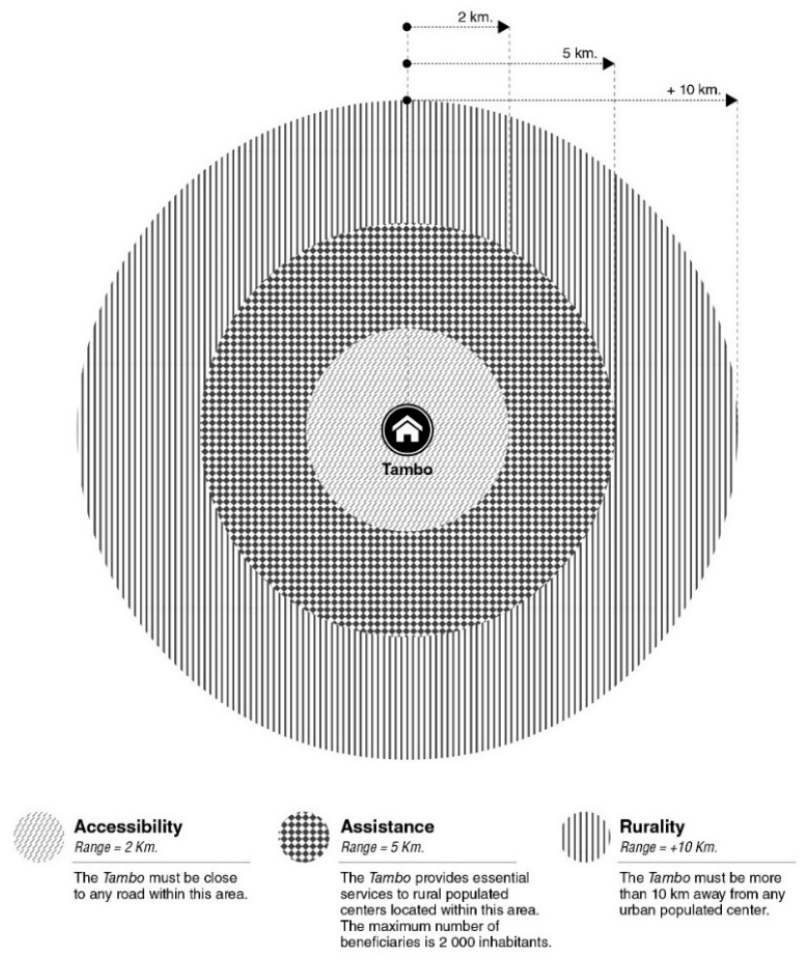

Figure 4. The location rules and influence area of the tambos (source: author, elaboration based on MIDIS, 2017)

\section{Methodology}

The exact data of the influence areas and georeferencing of the current tambos were provided directly by the "National Program of Tambos" in CSV format. The georeferenced data includes geographic coordinates, population size, natural region, and altitude of the tambos independently. The ArcGIS software and its "spatial analysis and geoprocessing" tools have been used to process the georeferenced data.

Data of the activities carried out in the current tambos was collected through the digital monitoring platform called tambook (Tambook, 2017). The tamberos (people in charge of managing a Tambo) use tambook to report in detail the daily activities through photographs and documents. These data are initially in web data format, and their extraction was through spreadsheet applications (Google Sheets). The results of the analysis of these data are shown through information visualization techniques using vector graphics editor (Adobe Illustrator) and opensource application (Mauri et al., 2017, p. 1).

For the climatic classification, the document "Climate Map for Architectural Design" was used as a technical basis (Rayter, 2008, p. 12). This document is based on Köppen's classification, which links the distribution of vegetation, altitude, radiation, thermal inversion, and traditional architecture, among other factors. Consequently, this technical document allows us to approach natural regions of architectural equivalence.

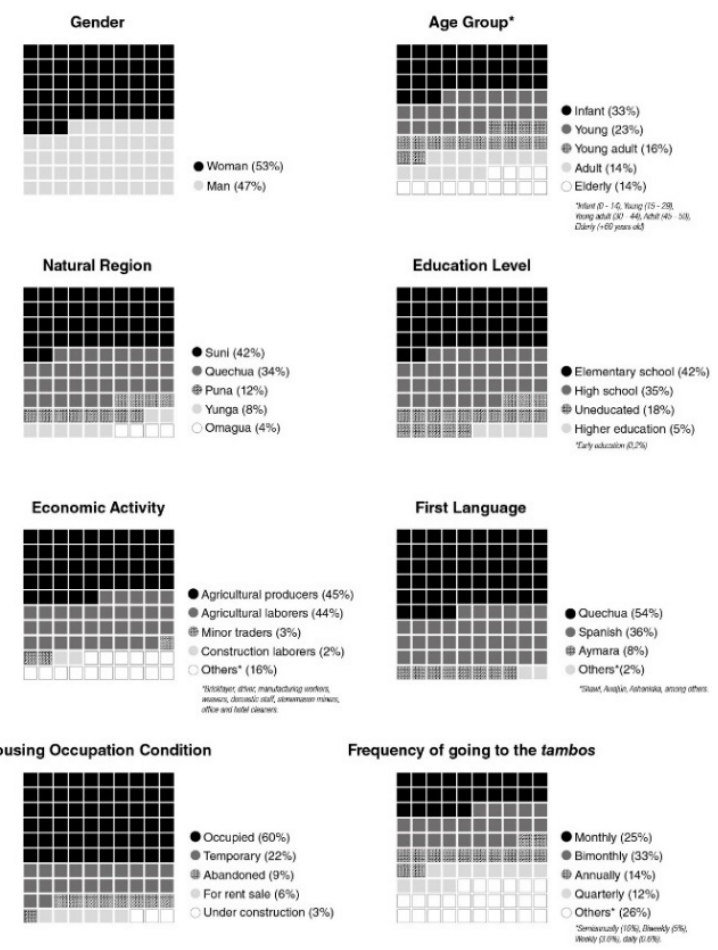

Figure 5. Main characteristics of the population benefited by the tambos (source: author, elaboration with data from Chumacero, 2015)

The scope of this research is of a strategic design nature at a national level. This scope means that a quantitative analysis of the georeferenced locations and influence area of the tambos is carried out. This preliminary analysis is complemented by a qualitative analysis through interviews with tamberos and officials of the "National Program of Tambos" Through the synthesis of these analyses, the design strategy is formulated to plan future tambos with a systematic vision of the Peruvian national territory.

\section{Results}

The "National Program of Tambos" (NPT) has tried to improve the architectural approach of the tambos to increase its built area and systematize its construction ${ }^{10}$. This effort has been laudable; however, they are still insufficient actions because it is still centered under a single architectural scheme. The Tambo's built area has increased from 300 to 500 square meters; however, its architectural program and compact form continue to be indifferent to the natural region where it is located. This indifference is not only in matters of climate but also in the offer of spaces that the tambos as a rural facility can provide to its different influence area (Figure 6). Therefore, for future tambos to be able to link up with the different territories where they will be located, these buildings must be multi-scale and

${ }^{10}$ Some tambos have adopted passive ventilation techniques as improvements to the construction system. 


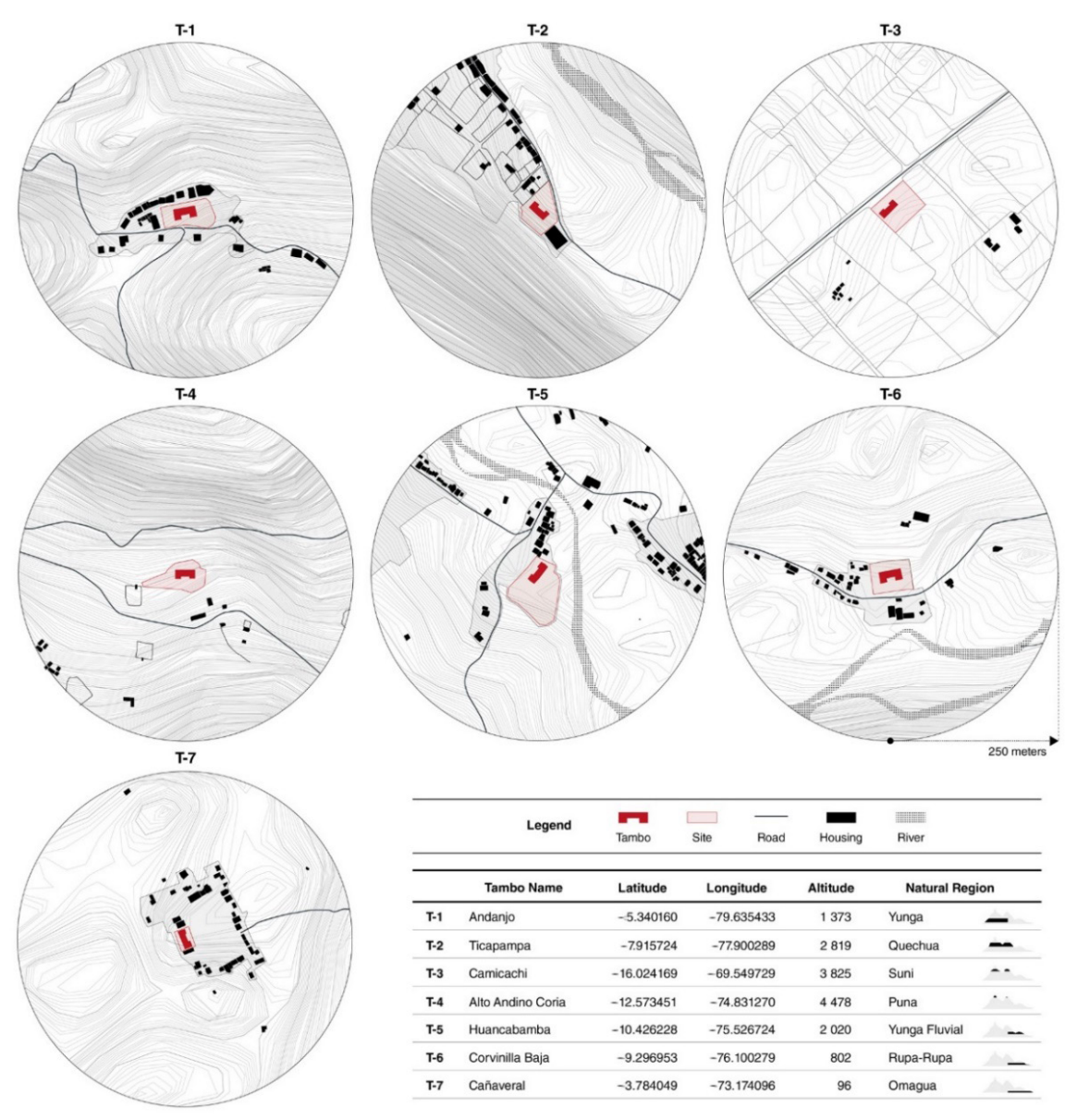

Figure 6. Examples of the tambos physical context in different natural regions (source: author)

multi-programmatic. These characteristics mean that, in the influence area of the future tambos, we will find populated rural centers of different population sizes and, consequently, heterogeneous service requirements. Therefore, the building of the tambos must have the quality to adapt dimensionally and programmatically to this demand of architectural spaces. This adaptation will allow tambos to perform the services effectively and according to the logic of the Peruvian rural landscape.

\subsection{The climatic classification}

The three typical regions (coast, highlands, and jungle) of Peru are an overly simplistic classification coming from the delimitation of the Peruvian territory (Seminario, 2016 , p. 441) in the 16th century that had an Iberian influence by the Spanish conquerors (Crousse, 2017, p. 27). This classification with western criteria prevailed ${ }^{11}$ for a long time and became generalized in publications and official media of the Peruvian government. The inert triple division was dangerously naive as it "homogenized" many sectors of Peru, and was intentionally evasive to the complexity of Peruvian geography (Flores et al., 1999, p. 8).

\footnotetext{
${ }^{11}$ This classification was recorded by Pedro Cieza de León in his book "Cronica del Peru" (1533).
}

So, what geographical classification should we consider for architectural design?

The Peruvian geographer Javier Pulgar Vidal presented in 1941, as a result of exhaustive research ${ }^{12}$, his thesis "The Eight Natural Regions of Peru” which consisted of the following regions classified mainly ${ }^{13}$ by their altitude: Chala, Yunga (this region is divided into two: Yunga and Fluvial Yunga), Quechua, Suni, Puna, Janca, Rupa-Rupa and Omagua (Vidal, 2014 , p. 12). The "Eight Natural Regions of Peru" (Figure 7) were the most exact and would revolutionize differentiation of that time; and would become the most critical study made on the geographical division of Peru, displacing the traditional "Coast, Highlands and Jungle". Although later there were also valuable contributions, it was Javier Pulgar Vidal who systematized this transversal look at Peruvian geography.

\footnotetext{
${ }^{12}$ Javier Pulgar Vidal considered previous publications by renowned Peruvian scientists. Among them are José de la Riva Agüero "Peruvian Landscapes (1912)", Julio C. Tello "Ancient Peru (1929)", Ricardo Bustamante Cisneros "Human Geography of Peru (1930)", Pedro M. Benvenutto Murrieta "The Peruvian Language (1932)", Aurelio Miró Quesada Sosa "Coast, Highlands and Mountains (1940)", and Pedro E. Paulet with his thesis on the "five natural regions".

${ }^{13}$ The following criteria were also considered: climatic, ecological, toponymic, and human activity (Vidal, 2014, pp. 8-12).
} 

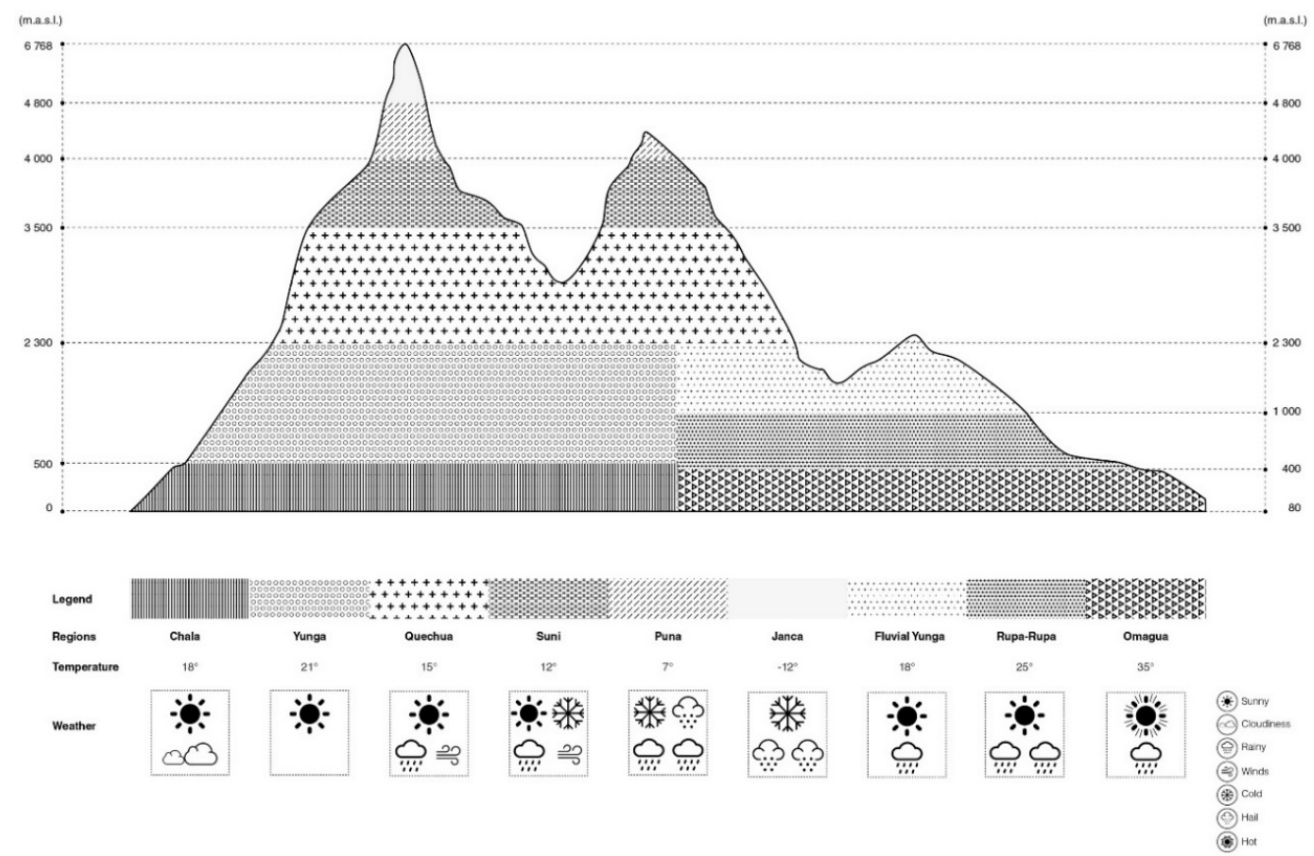

Figure 7. Transversal section of the "Eight Natural Regions of Peru" (source: author, elaboration based on Vidal, 2014)

Table 2. Altitudinal equivalence between natural regions and climatic zones

\begin{tabular}{|c|c|c|c|c|c|c|c|}
\hline \multirow{2}{*}{$\begin{array}{c}\text { Natural regions } \\
\text { (Javier Pulgar Vidal) } \\
\text { m.a.s.l. }\end{array}$} & \multicolumn{7}{|c|}{ Climatic zones (Rayter, 2008) } \\
\hline & $\begin{array}{l}\text { Climatic zones } \\
\text { (m.a.s.l.) }\end{array}$ & $\begin{array}{c}\text { Minimum } \\
\text { temperature } \\
\left({ }^{\circ} \mathrm{C}\right)\end{array}$ & $\begin{array}{c}\text { Maximum } \\
\text { temperature } \\
\left({ }^{\circ} \mathrm{C}\right) \\
\end{array}$ & $\begin{array}{l}\text { Rainfall } \\
(\mathrm{mm})\end{array}$ & $\begin{array}{c}\text { Relative } \\
\text { humidity } \\
(\%)\end{array}$ & $\begin{array}{l}\text { Wind } \\
\text { Speed } \\
(\mathrm{m} / \mathrm{s})\end{array}$ & $\begin{array}{c}\text { Sun hours } \\
(\mathrm{h} / \mathrm{d})\end{array}$ \\
\hline $\begin{array}{l}\text { Chala } \\
0-500\end{array}$ & $\begin{array}{l}\text { Marine Desert } \\
0-400\end{array}$ & $19^{\circ}$ & $21^{\circ}$ & 150 & $+70 \%$ & $11 \mathrm{~m} / \mathrm{s}$ & $5 \mathrm{~h} / \mathrm{d}$ \\
\hline $\begin{array}{c}\text { Yunga } \\
500-2300\end{array}$ & $\begin{array}{c}\text { Desert } \\
400-2000\end{array}$ & $10^{\circ}$ & $30^{\circ}$ & 500 & $50 \%$ & $11 \mathrm{~m} / \mathrm{s}$ & $6 \mathrm{~h} / \mathrm{d}$ \\
\hline $\begin{array}{l}\text { Quechua } \\
2300-3500\end{array}$ & $\begin{array}{l}\text { Inter-Andean Low } \\
2000-3000\end{array}$ & $11^{\circ}$ & $23^{\circ}$ & 1500 & $30 \%$ & $7 \mathrm{~m} / \mathrm{s}$ & $7 \mathrm{~h} / \mathrm{d}$ \\
\hline $\begin{array}{c}\text { Suni } \\
3500-4000\end{array}$ & $\begin{array}{l}\text { Mesoandino } \\
3000-4000\end{array}$ & $9^{\circ}$ & $19^{\circ}$ & 2500 & $30 \%$ & $10 \mathrm{~m} / \mathrm{s}$ & $8 \mathrm{~h} / \mathrm{d}$ \\
\hline $\begin{array}{c}\text { Puna } \\
4000-4800\end{array}$ & $\begin{array}{c}\text { High Andean } \\
4000-4800\end{array}$ & $-3^{\circ}$ & $17^{\circ}$ & 2500 & $30 \%$ & $9 \mathrm{~m} / \mathrm{s}$ & $9 \mathrm{~h} / \mathrm{d}$ \\
\hline $\begin{array}{c}\text { Janca } \\
4800-6768\end{array}$ & $\begin{array}{c}\text { Snowy } \\
4800-6768\end{array}$ & $-20^{\circ}$ & $15^{\circ}$ & 750 & $30 \%$ & $7 \mathrm{~m} / \mathrm{s}$ & $10 \mathrm{~h} / \mathrm{d}$ \\
\hline $\begin{array}{c}\text { Fluvial Yunga } \\
2300-1000\end{array}$ & $\begin{array}{c}\text { Mountain Eyebrow } \\
3000-2000 \\
\end{array}$ & $10^{\circ}$ & $17^{\circ}$ & 6000 & $+70 \%$ & $7 \mathrm{~m} / \mathrm{s}$ & $9 \mathrm{~h} / \mathrm{d}$ \\
\hline $\begin{array}{l}\text { Rupa-Rupa } \\
1000-400\end{array}$ & $\begin{array}{l}\text { Humid subtropical } \\
2000-400\end{array}$ & $21^{\circ}$ & $27^{\circ}$ & 4000 & $+70 \%$ & $7 \mathrm{~m} / \mathrm{s}$ & $5 \mathrm{~h} / \mathrm{d}$ \\
\hline $\begin{array}{l}\text { Omagua } \\
400-80\end{array}$ & $\begin{array}{c}\text { Tropical wet } \\
400-80\end{array}$ & $21^{\circ}$ & $31^{\circ}$ & 4000 & $+70 \%$ & $6 \mathrm{~m} / \mathrm{s}$ & $4 \mathrm{~h} / \mathrm{d}$ \\
\hline
\end{tabular}

Note: Data are from Rayter (2008).

In 2005, architects Rayter, Fuster, and Zuñiga proposed the "Climate Map for Architectural Design" (Rayter, 2008 , p. 12), which was finally adopted by the Peruvian government ${ }^{14}$ to promote the construction of bioclimatic buildings in the public sector through infrastructure pro-

\footnotetext{
${ }^{14}$ Through the Ministry of Housing, Construction, and Sanitation, the regulatory project "Technical Code for Sustainable Construction" was promoted.
}

grams ${ }^{15}$. This "Climate Map for Architectural Design" classifies Peru into nine climate zones, and it is interesting to note that this classification coincides with the altitudinal ranges of Javier Pulgar Vidal's "Eight Natural Regions" (Table 2). This equivalence is potentially beneficial to the

\footnotetext{
15 The Ministry of Education of the Peruvian government adopted this study to design the project "Plan Selva" - Educational Infrastructure for the Rural Amazon in 2015.
} 


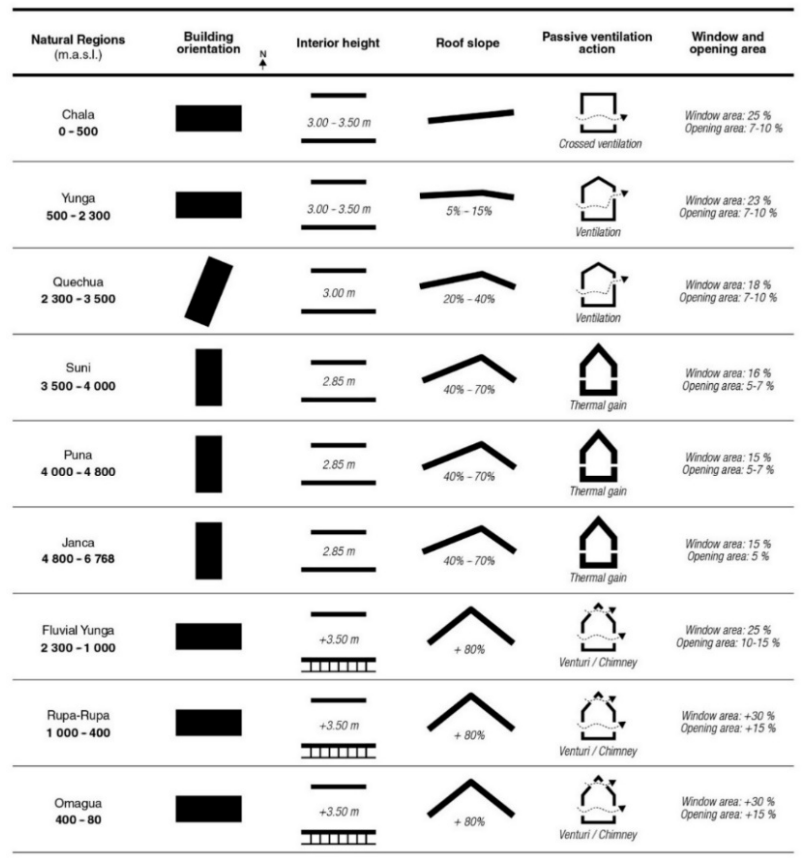

Figure 8. Design Guidelines according to the Natural Regions of Peru (source: author, elaboration based on Rayter, 2008)

"National Program of Tambos" because the tambos are currently managed according to the altitudinal floors.

In 2008, based on the "Climate Map for Architectural Design", the Peruvian government proposed some "specific design recommendations" (Rayter, 2008, pp. 13-55), which, although initially intended for educational premises, many of these could also be applied to other building typologies. With this information, synthesis has been made (Figure 8) of those recommendations that could be successfully applied in the design of future tambos. The design recommendations have been classified into five categories: (1) the orientation of the building concerning the north in order to take advantage of or avoid solar incidence, (2) the minimum internal and useful height of the building that ensures correct comfort, (3) the minimum slope of the roofs that allow adequate action against the force of rainfall, (4) passive ventilation techniques; and, finally, (5) the percentage of the windows opening for lighting.

\subsection{Spontaneous activities}

The tambos have a similar architectural program (Figure 9) in any area of the national territory because the interior spaces' list has remained unchanged. Nevertheless, it has been evident that the tambos have also come to house other activities within their boundaries. This occupation is because, although the tambos have around 300 square meters $\left(\mathrm{m}^{2}\right)$ of built area, the land legally owned by them is vast, ranging from 1500 to 3000 square meters (Figure 10). The activities carried out within these boundaries include spontaneous uses that have appropriated the dairy according to their territory and respond to the real socialproductive demands of their respective influence areas.

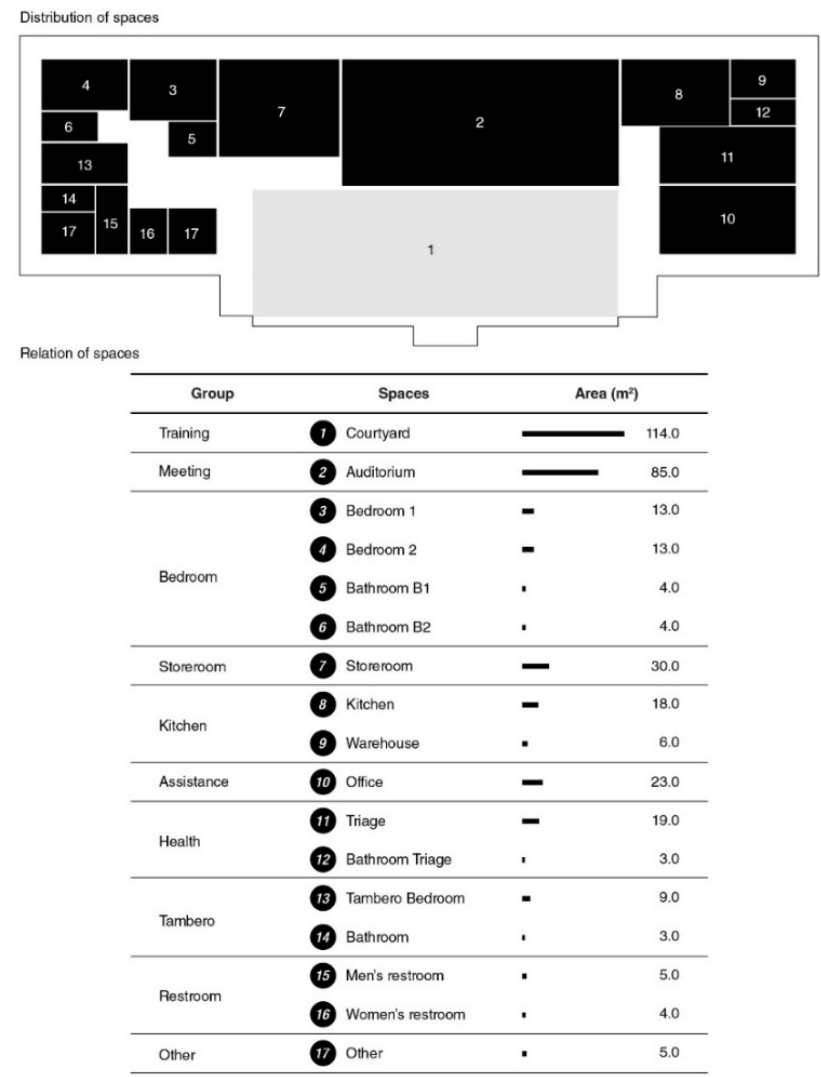

Figure 9. Distribution of spaces in a typical Tambo (source: author)

Eight typologies of spontaneous activities have been identified that take place in the tambos. The following variables can organize these typologies: Natural region, age groups (child, youth, adult and elderly); and the type of space that the activity occupies, whether it is open (on the land of the tambos), semi-open (in the front yard that every tambos has) or closed (inside the tambos). The eight typologies are:

1) Agricultural: Activities to strengthen the productive capacities of the field. These activities take advantage of the tambos' land to implement demonstration bio-gardens or to teach improvement techniques for domestic and livestock animals.

2) Health: Activities that contribute to improving the health indicators of the population. They include vaccination campaigns to lectures to fight anemia. Due to their informative character, these activities are carried out mostly inside the tambos and semiopen spaces. Children and the elderly are the priority age group.

3) Organizational: Activities that strengthen the organization of resources (agricultural soil and water) and avoid conflicts between farming communities. The primary use is of the interior space of the tambos since it is mostly for training workshops, although massive meetings have also been found in the open space of the tambos. These activities are 

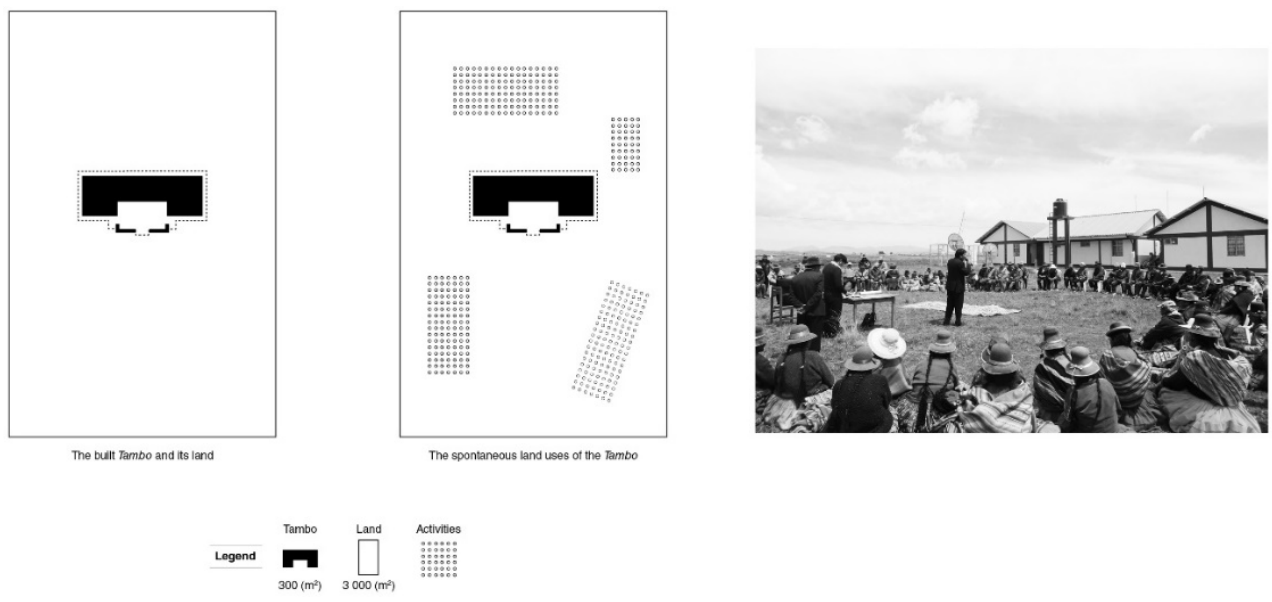

Figure 10. The land use of a typical Tambo for community meeting (source: MIDIS, 2014)

mainly oriented to young people and adults since they are the ones who assume leadership in the communities.

4) Education: Training activities aimed at students and teachers in the use of digital-technological tools. These activities are carried out inside the tambos through the use of computers. Children and young people are the primary beneficiaries.

5) Environmental management: Activities aimed at the conservation of natural resources and risk mitigation in the face of natural phenomena. Semi-open spaces (such as the playground) and open spaces are mostly used by the mass of people carrying out the activity (for example, in multi-hazard drills).

6) Culture: One of the most successful activities of this group is the "cinema forum", which is the projection of a national documentary accompanied by a discussion according to the theme. This event has a large number of children and young people. This type of collective activity is carried out, not only inside, but also outside the tambos for environmental comfort.

7) Financial: Activities aimed at encouraging economic entrepreneurship. Talks and fairs (labor or agricultural product sales) are held. The full use is of semi-open spaces, which are useful to generate virtual covers.

8) Equipment: Assistance activities that deliver emergency goods to vulnerable populations. For logistical reasons, the front yard of the tambos is used because it is semi-open and is close to the administrative offices.

These spontaneous activities show that the compact configuration of the current tambos is insufficient to correctly accommodate the real demand for activities in their respective spheres of influence; therefore, the architectural approach of future tambos must be versatile. This characteristic means that future tambos must make the most of the land they have through a multi-scale and multiprogrammatic configuration. In addition to this, and as we have mentioned before, we do not know what exact geo-

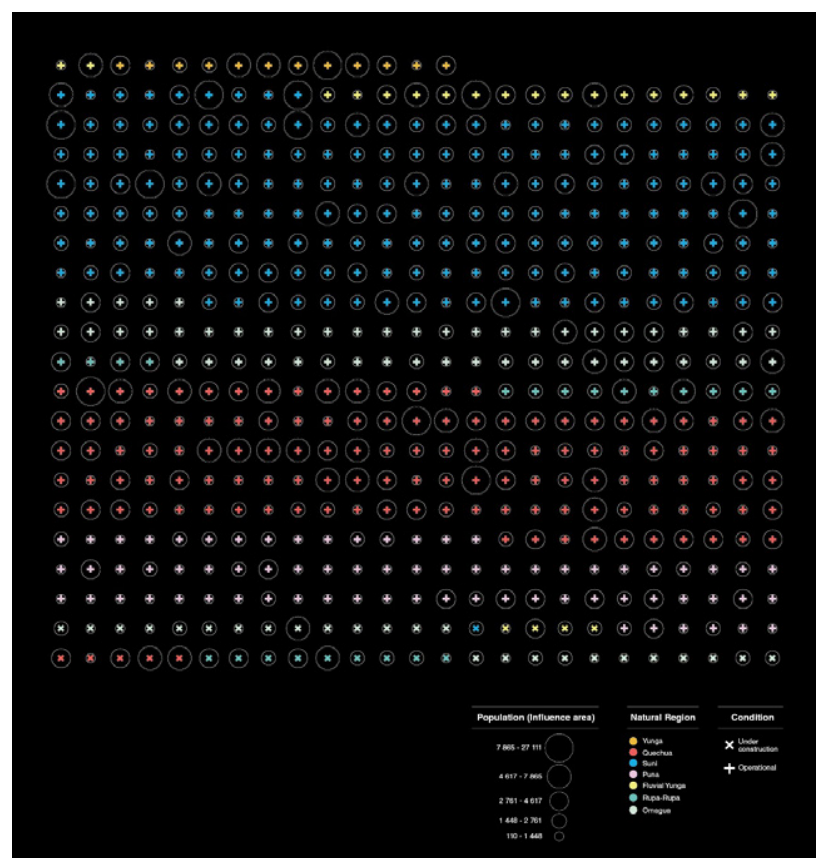

Figure 11. Analysis of the current 514 tambos (source: author, elaboration with data from Tambook, 2017)

graphic or demographic conditions our future tambos will be exposed. The current tambos are located in different regions and have different population sizes (Figure 11). Therefore, the project strategy proposed is to develop a "systematic catalog", which means groupings of components allow us to consider all the project possibilities to implement future tambos in any point of the Peruvian rural territory.

\subsection{The systematic catalog}

The design strategy is called "systematic catalog" as a resource to explain the high degree of synthesis in the optimal grouping of different components and variables in order for these elements to operate as a system; that is, they follow specific guidelines to achieve the design purpose as a set of actions. 
Initially, five types of modular schemes have been proposed (Figure 12) that will serve as spatial outlines to initially configure the systematic catalog. These modular diagrams have been strategically designed so that their geometry and area can accommodate different activities. The correct combination of these modular elements will provide a flexible program for future tambos. This flexible combination means that these modular schemes are not tambos by themselves, but are spatial sketches that will be transformed by the variable of the natural region when putting into the systematic catalog.

The systematic catalog (Figure 13) is organized mainly by territorial constraints; this means it is limited to the al-
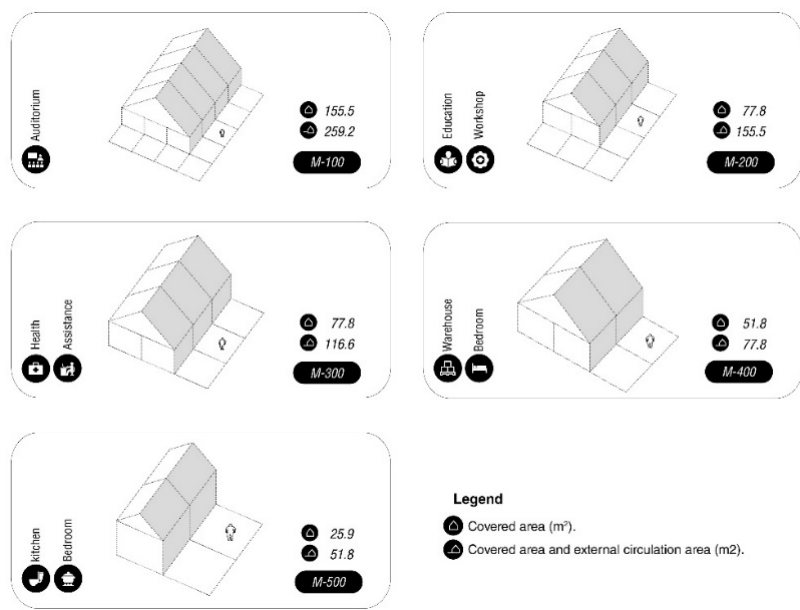

Figure 12. The modular schemes and possible uses (source: author) titudinal levels (The eight natural regions by Javier Pulgar Vidal) described in the previous subchapters. It is worth mentioning that the "Chala" region has been excluded because it is considered an area of high socio-economic development and, therefore, of no priority for the "National Program of Tambos". Likewise, the "Janca" region ${ }^{16}$ has been excluded because it is an area not suitable for population settlements due to its extreme climatic conditions. From these exclusions, the systematic catalog finally includes seven natural regions; nevertheless, these have been synthesized in 3 groups that keep similarity by their climatic conditioners towards the architectural design:

- Sierra: includes the "Yunga" and "Quechua".

- Frost: includes the "Suni" and "Puna".

- Rainforest: includes the "fluvial Yunga", "Rupa-Rupa", and "Omagua".

The formation of these groups obeys to a resource to organize the systematic catalog's project intentions. This organizational resource means that the disposition of these three groups with their respective natural regions governed by the altitude floor optimizes the communication of the functioning of the systematic catalog.

In the systematic catalog (Figure 13), the cross between the five modular schemes and the three groups of natural regions gives us 15 "primary modules" with their respective variations according to the specific natural region in which they are found. The specific design recommendations developed previously in this research have been followed for the generation of these primary modules. The primary modules are organized as follows:

- Sierra: These modules mainly seek to take advantage of zenithal solar radiation and avoid cold horizontal

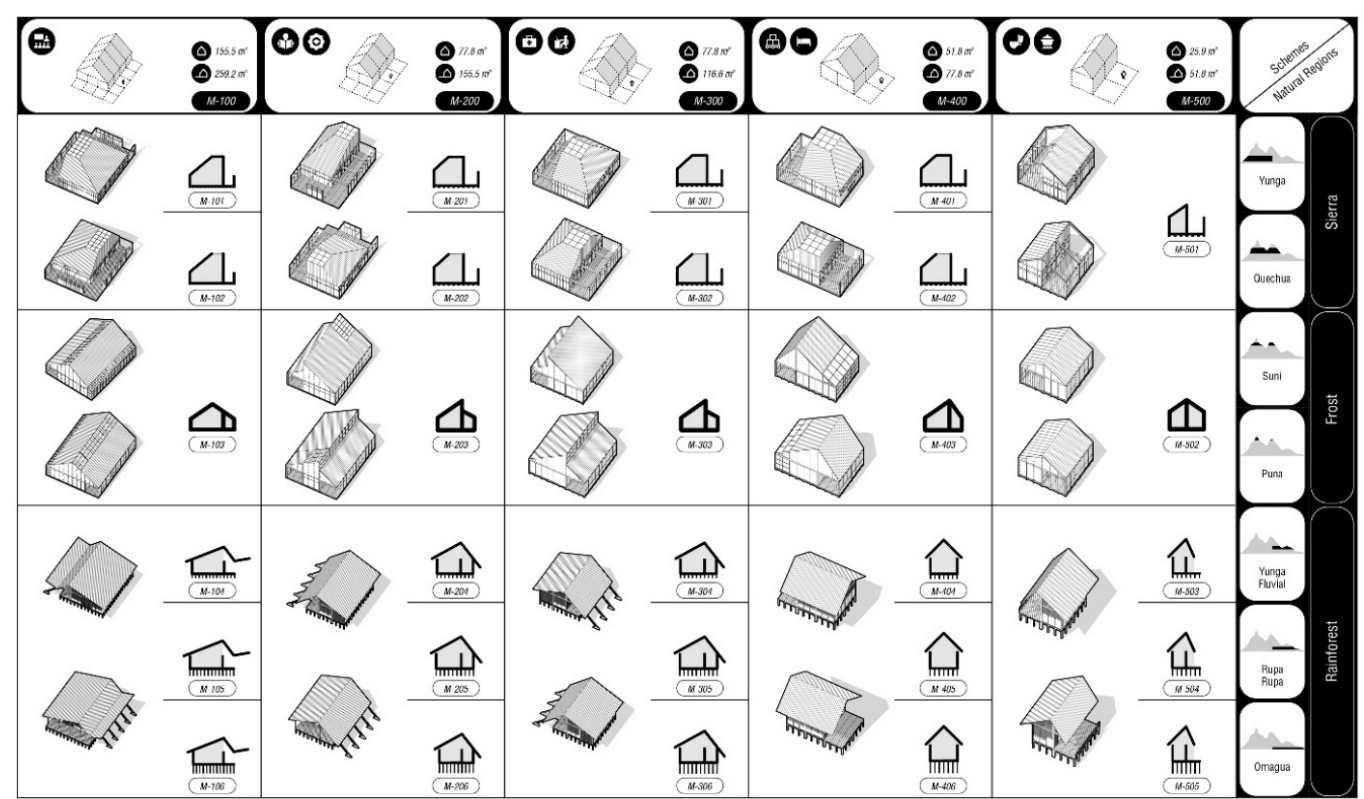

Note: The primary modules are shown in two views (front and back).

Figure 13. The systematic catalog: primary modules (source: author)

${ }^{16}$ The Janca region is considered a glacial zone because it is above 4800 meters above sea level. 


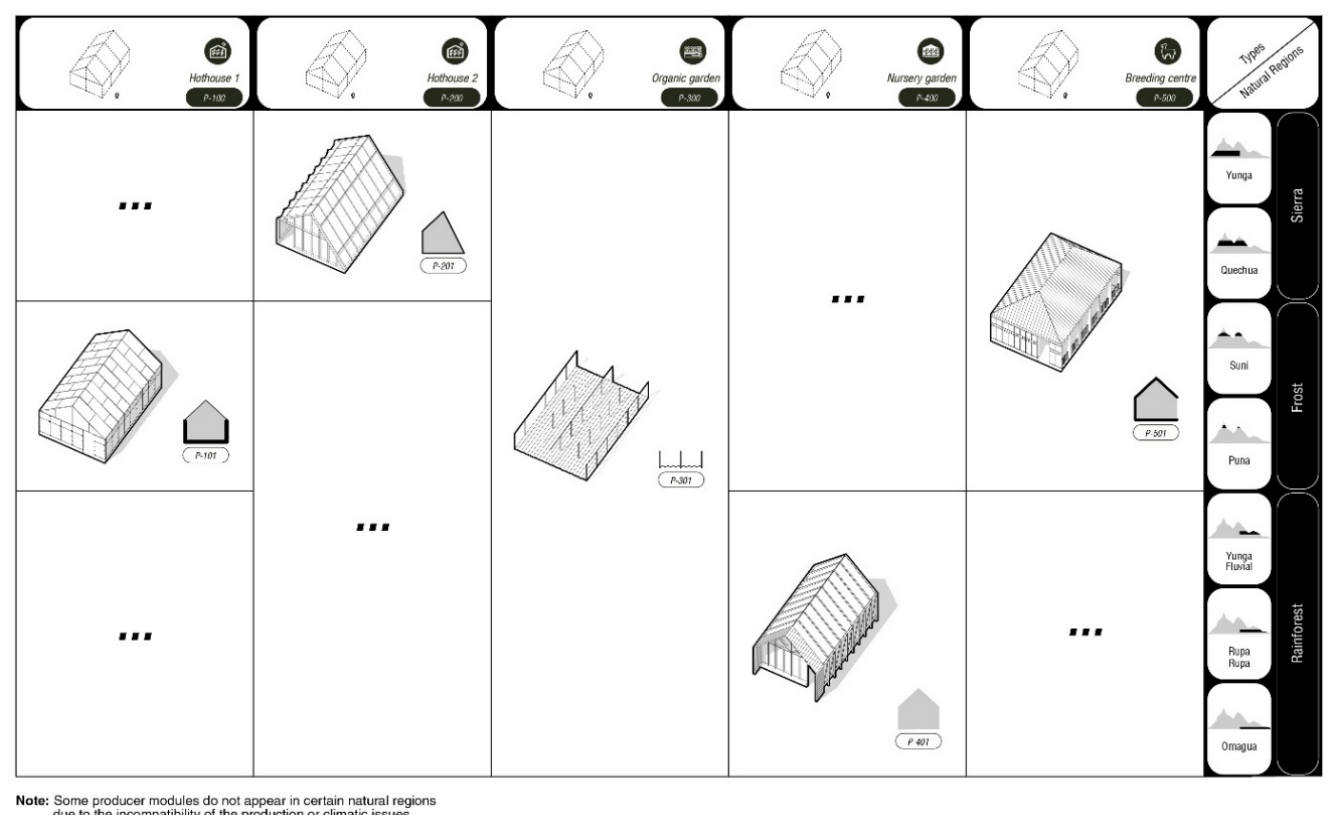

Figure 14. The systematic catalog: producer modules (source: author)

winds. Likewise, the moderate slope of the roof is essential for rainfall in these natural regions.

- Frosts: These modules are hermetic and seek to generate a greenhouse effect to gain heat inside. The interior height is reduced to the minimum permissible (2.40 meters) to conserve heat, and the slope of the roof is increased to deal with rain and hail from recurrent frosts.

- Rainforest: These modules have a high interior height (3.60 meters) for proper ventilation, and to this is added the high slope $(80 \%)$ of the roof to cope with heavy rainfall. Also, the modules of this group are elevated above the ground to adapt to Amazon's many river floods. The gap above ground is varied $(0.45,0.90$, and 1.50 meters) according to the level of flooding that occurs at each altitudinal level ("Fluvial Yunga", "Rupa-Rupa" and "Omagua").

The systematic catalog is complemented by the "producer modules" (Figure 14). These are so called because they are for the instructive use of agricultural-food capacities (bio-garden, greenhouse, and nursery) and the training of livestock improvement (breeding module). These production modules also have their respective variations according to the regional group where they are located:

- Sierra: The greenhouse in this region takes advantage of solar radiation through the angle of its roof.

- Frost: The greenhouse for this region seeks to retain more heat gain due to the thickness of its base walls near the ground.

- Rainforest: The nursery would only be a light system to "protect" the crop because the high temperatures of the Amazon already provide the right climate for native plants.

The bio-garden is proposed only as a portion of soil that can be cultivated in the open air and transversal to any natural region.
The primary modules and producer modules would be connected by horizontal circulation such as walkways, ramps, and stairs suitable for their respective natural region. Besides, these connecting elements would make possible the generation of squares, platforms, or patios that would become meeting places within the boundaries of the future tambos.

\section{Discussion}

Through its primary modules and producer modules, the systematic catalog allows the creation of different configurations (Figure 15) for future tambos. These configurations will make possible tambos with different sizes and programs according to the requirements of their fields of influence. Also, the configurations would have the capacity to adapt to the topographical irregularity of the available land formally; therefore, the location, extension, and use of the available boundaries would be optimized due to the modular layout of the location of the future tambos.

On the other hand, the systematic catalog allows the implementation of the tambos to be carried out in temporary phases (Figure 16) according to the national strategy $^{17}$ against poverty that responds to the degree of vulnerability of the respective influence area of the tambos. These phases are used to demonstrate that the architectural intervention can be adapted to the objectives of state initiatives such as the "National Program of Tambos".

These implementation phases would be the following:

- Phase 1: Poverty Relief. In this first phase of implementation, the primary modules needed to provide

${ }^{17}$ The national strategy for development and social inclusion is called "Include to grow". This strategy promotes interventions articulated in different terms: short (relief), medium (autonomy), and long term with future generations (Kámiche, 2015, p. 10). 


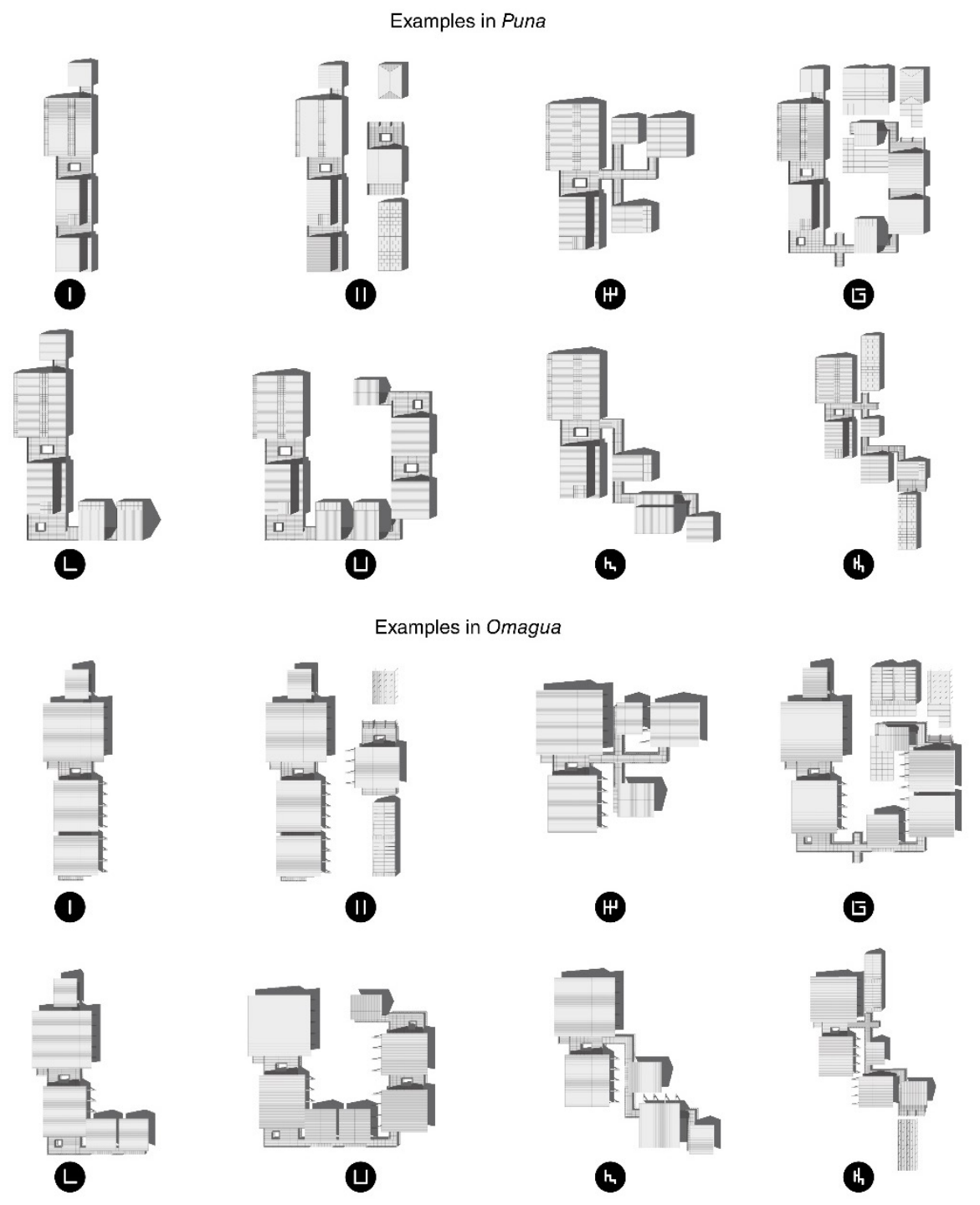

Figure 15. Possible configurations of future tambos (source: author)

urgent social assistance to the population are installed. For this, the public hygienic services are placed, a module for the drummer's bedroom, and a module for the care office. The square, access to the tambos, and its essential equipment for the supply of drinking water (cistern), internet (satellite antenna), and electric power are also defined through different alternatives (Jensen et al., 2019).

- Phase 2: Capacity strengthening. In this phase, the producer modules are added to form a program that allows for agricultural instruction. Therefore, the greenhouse, bio-garden, and a space for in situ training of livestock are installed. Likewise, a structure is placed that allows for a light cover to house temporary fairs. Besides, a tank for training instruments and a module for the kitchen are added.

- Phase 3: Guaranteeing opportunities. This last phase tableks to lay the foundations so that poverty does not return to these communities. To this end, the implementation of the future tambos is completed by installing the programmatic modules aimed at educational and cultural aspects. Likewise, the free space is activated with elements of play and meeting/rest. In addition to this, other alternative technology equipment is also installed (Peralta Vera et al., 2019).

With the systematic catalog and its implementation phases, the future tambos would become a rural square for the population center because it would behave as an attractor agent in its influence area. This quality means that, given the lack of public facilities in highly dispersed rural areas, many houses would choose to settle near the tambos in search of more direct access to essential services. Consequently, a recognizable area of concentration would be generated around future tambos. This demand is currently occurring in a disorderly manner; however, with the systematic catalog as design strategy, the future tambos could respond more effectively because it would adapt to the real demands of their population of influence. 

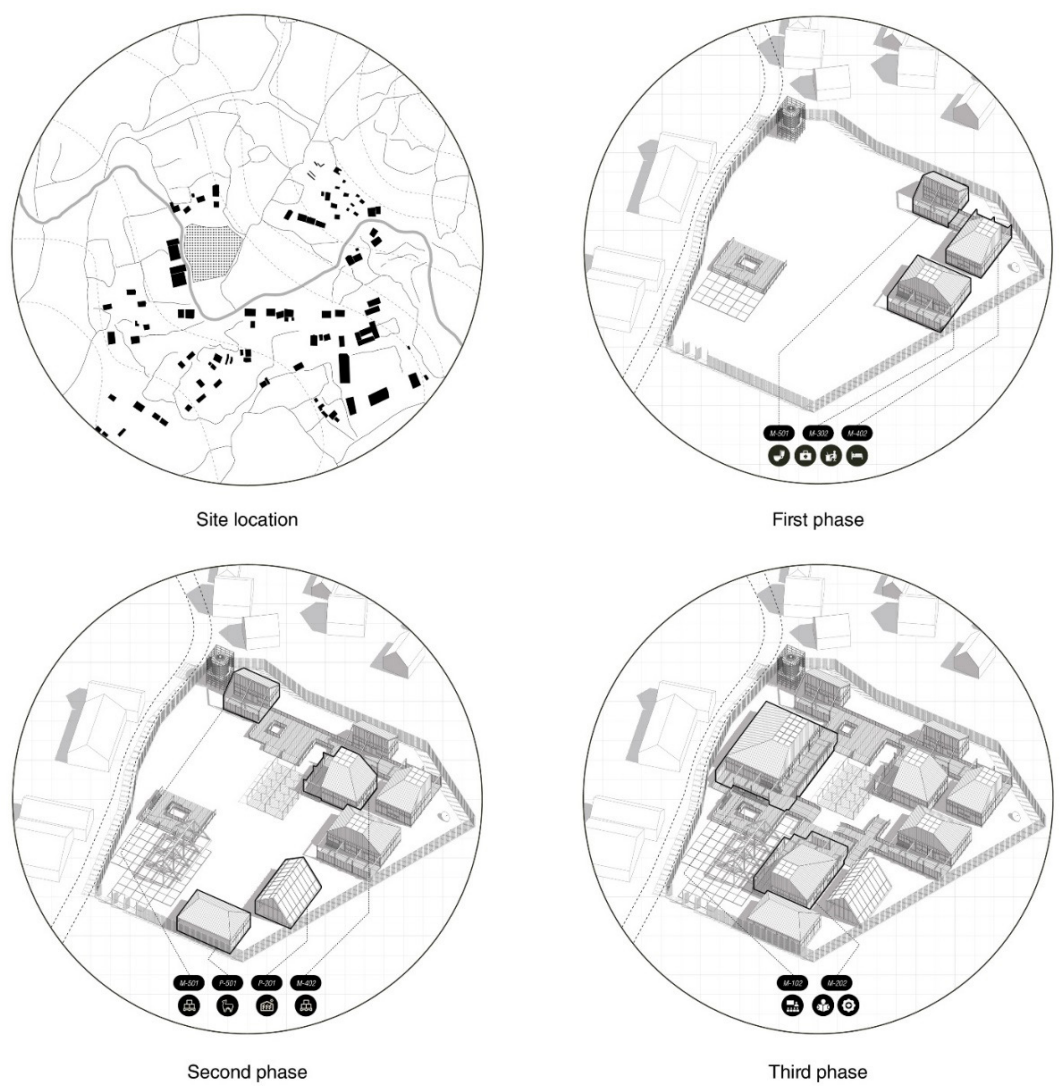

Figure 16. Implementation phases for future tambos (source: author)

\section{Conclusions}

The "National Program of Tambos" (NPT) has great potential in its institutional initiative to reach the most dispersed and vulnerable populations. However, this initiative does not end up meeting all the expectations because the current approach of the NPT for the Peruvian territory is insufficient to understand all the variables that make it up. Therefore, the findings of this research show that the NTP must change its vision regarding its physical performance in the rural territory; and it is here where the disciplinary field of architecture can contribute from the convergence of design variables. In this context, the systematic catalog must be the design strategy to massively implement the future tambos in different locations of the rural territory because it allows the synthesis of the complexity of the Peruvian geography through the correct classification of architectural components. Therefore, this modular system outlines an ideal scenario for the "National Program of Tambos", where understanding the link between architecture and the natural regions of Peru will predominate.

Rurality in the world and Peru is no longer as we imagined before due to increasingly rapid social and economic changes. Agricultural activity has been complemented with other services in the search to insert added value to its production (Rodríguez, 2016, p. 12). Also, households previously dedicated exclusively to agriculture are now beginning to engage in other non-agricultural economic sectors (Srinivasan \& Rodríguez, 2016, p. 18). These dynamics demand that our architectural discipline carry out more rigorous studies on the rural world to avoid prejudices towards these populations, causing us to operate in an outdated way. A change of paradigm is needed so that architecture can contribute to rural and urban development (Sutherland, 2018). Therefore, the present article has shown that it is possible to consider all of Peru as a tremendous operational field for architecture. From its integral study, it is possible to obtain project inputs for future government initiatives in national infrastructure without distinction between urban and rural.

\section{Funding}

This research did not receive any specific grant from funding agencies in the public, commercial, or not-for-profit sectors.

\section{Disclosure statement}

The author declares that he has no known competing financial interests or personal relationships that could have appeared to influence the work reported in this paper. 


\section{References}

Branca, D. (2019). The urban and the rural in Puno, highland Peru. Anthropology Today, 35(6), 18-20. https://doi.org/10.1111/1467-8322.12542

Chumacero, E. (2015). Resultados del empadronamiento de la Población y Vivienda en el Ámbito de Influencia de los Tambos. Instituto Nacional de Estadística e Informática (INEI). http:// www.pais.gob.pe/webpais/public/publicaciones/estudio_inei

Crousse, J. P. (2017). El Paisaje Peruano. Fondo Editorial PUCP. de Ferranti, D., Perry, G., Foster, W., Lederman, D., \& Valdes, A. (2005). Beyond the city: the rural contribution to development (World Bank Latin American and Caribbean Studies). The World Bank. https://doi.org/10.1596/0-8213-6097-3

Di Liscia, M. S. (2017). Del brazo civilizador a la defensa nacional: políticas sanitarias, atención médica y población rural (Argentina, 1900-1930). Historia Caribe, 12(31), 159-193. https://doi.org/10.15648/hc.31.2017.6

Dirven, M. (2019). Nueva definición de lo rural en América Latina y el Caribe en el marco de FAO para una reflexión colectiva para definir líneas de acción para llegar al 2030 con un ámbito rural distinto. Organización de las Naciones Unidas para la Alimentación y la Agricultura (FAO).

http://www.fao.org/family-farming/detail/en/c/1241488/

Dirven, M., Echeverri, R., Sabalain, C., Candia, D., Faiguenbaum, S., Rodríguez, A., \& Peña, C. (2011). Hacia una nueva definición de "rural" con fines estadísticos en América Latina. Comisión Económica para América Latina y el Caribe (CEPAL). https://www.cepal.org/es/publicaciones/3858-nuevadefinicion-rural-fines-estadisticos-america-latina

Eguren, F. (2016). Seguridad Alimentaria en el Perú: Compendio de artículos publicados en La Revista Agraria 2010-2015. Centro Peruano de Estudios Sociales (CEPES), Lima, Perú. https://www.researchgate.net/profile/Fernando-Eguren/publication/307559265_Seguridad_Alimentaria_en_el_Peru/ links/57c853b908aefc4af34ec546/Seguridad-Alimentaria-enel-Peru.pdf

Escobal D’Angelo, J., \& Torero, M. (2000). How to face an adverse geography: the role of private and public assets. Group for the Analysis of Development (GRADE).

Flachsbarth, I., Schotte, S., Lay, J., \& Garrido, A. (2018). Rural structural change, poverty and income distribution: evidence from Peru. The Journal of Economic Inequality, 16(4), 631653. https://doi.org/10.1007/s10888-018-9392-Z

Flores, A., Wagner, A., Córdova, H., \& Bernex, N. (1999). Javier Pulgar Vidal: geógrafo del Perú. (Cuadernos de Archivo de la Universidad, 10). Pontificia Universidad Católica del Perú (PUCP). http://repositorio.pucp.edu.pe/index/handle/123456789/28679

Haudry de Soucy, R. (2013). Dar a la población rural pobre del Perú la oportunidad de salir de la pobreza. International Fund for Agricultural Development (IFAD). https://www.ifad.org/en/

Instituto Nacional de Estadística e Informática. (2017). Perú resultados definitivos de los censos nacionales 2017 (Tomo I: Aspectos generales). https://www.inei.gob.pe/media/MenuRecursivo/publicaciones_digitales/Est/Lib1544/

Insituto Nacional de Estadística e Informática. (2018a). Directorio nacional de municipalidades provinciales, distritales y centros Poblados. Instituto Nacional de Centros Poblados. https:// www.inei.gob.pe/media/MenuRecursivo/publicaciones_digitales/Est/Lib1514/

Insituto Nacional de Estadística e Informática. (2018b). Mapa de pobreza monetaria provincial y distrital 2018. https://www. inei.gob.pe/media/MenuRecursivo/publicaciones_digitales/ Est/Lib1718/Libro.pdf
Jensen, M., Hopps, E., \& Roth, B. (2019). Assessing the impact of off-grid solar electrification in rural Peru. International Journal for Service Learning in Engineering, Humanitarian Engineering and Social Entrepreneurship, 14(3), 61-79.

https://doi.org/10.24908/ijsle.v14i3.13194

Kámiche, J. (2015). Marco conceptual del Programa Nacional Tambos. Ministerio de Vivienda, Construcción y Saneamiento (MVCS). http://www.pais.gob.pe/webpais/public/publicaciones/marco_conceptual

Li Liza, W. (2016). Programa Nacional de Tambos: Memoria 2013 - 2015. Ministerio de Vivienda, Construcción y Saneamiento (MVCS). http://www.pais.gob.pe/webpais/public/publicaciones/memoria

Mauri, M., Elli, T., Caviglia, G., Uboldi, G., \& Azzi, M. (2017). RAWGraphs: A visualisation platform to create open outputs. In Proceedings of the 12th Biannual Conference on Italian SIGCHI Chapter (pp. 1-5), Cagliari, Italy. https://doi.org/10.1145/3125571.3125585

Ministerio de Economía y Finanzas. (2010). Reglamento de la Ley de Promoción para el Desarrollo de Actividades Productivas en Zonas Altoandinas (Decreto Supremo $N^{\circ}$ 051-2010-EF). https://www.mef.gob.pe/es/normatividad-sp-9322/por-temas/ ley-altoandinas

Ministerio de Desarrollo e Inclusión Social. (2014). Plataformas de acción para la inclusión social. https://www.pais.gob.pe/webpais/public/

Ministerio de Desarrollo e Inclusión Social. (2017). Manual de operaciones del Programa Nacional Tambos. https://www.gob. pe/institucion/midis/normas-legales/6473-189-2017-midis

Ministerio del Ambiente. (2019). Mapa nacional de ecosistemas del Perú. https://www.gob.pe/institucion/minam/informespublicaciones/277146-mapa-nacional-de-ecosistemas-del-peru

Morley, S. (2017). Changes in rural poverty in Perú 2004-2012. Latin American Economic Review, 26(1), 1-20. https://doi.org/10.1007/s40503-016-0038-x

Peralta Vera, A. A., del Carpio Beltrán, H. J., Zúñiga Torres, J. C., Milón Guzmán, J. J., \& Braga, S. L. (2019). Experimental Study of a photovoltaic direct current water pumping system for irrigation in rural-isolated region of Arequipa, Peru. Journal of Solar Energy Engineering, 141(4).

https://doi.org/10.1115/1.4042724

Preissing, J., Rodríguez, D., López, G., M, F., \& Bobadilla, P. (2016). Compendio de análisis del programa nacional Tambos. Ministerio de Vivienda, Construcción y Saneamiento (MVCS). http://www.pais.gob.pe/webpais/public/publicaciones/compendio

Puente, J. (2019). The military grammar of agrarian reform in Peru. Radical History Review, 2019(133), 78-101. https://doi.org/10.1215/01636545-7160077

Rayter, D. (2008). Guía de aplicación de arquitectura bioclimática en locales educativos. Ministerio de Educación (MINEDU). http://www2.congreso.gob.pe/sicr/cendocbib/con4_uibd. nsf/9A45F1BED1AB7C6705257CCA00550ABD/\$FILE/ GuiaBioclim\%C3\%A1tica2008.pdf

Remy, M. I. (2009). Las urbes, las ciudades y la población rural. Revista Argumentos, 3(2). https://argumentos-historico.iep. org.pe/articulos/las-urbes-las-ciudades-y-la-poblacion-rural/

Rodríguez, A. (2016). Transformaciones rurales y agricultura familiar en América Latina: una mirada a través de las encuestas de hogares. Comisión Económica para América Latina y el Caribe (CEPAL). https://repositorio.cepal.org/handle/11362/40078

Seminario, B. (2016). El desarrollo de la economía peruana en la era moderna: precios, población, demanda y producción desde 1700. Universidad del Pacífico. http://hdl.handle.net/11354/1160 
Srinivasan, S., \& Rodríguez, A. (2016). Pobreza y desigualdades rurales: perspectivas de género, juventud y mercado de trabajo. Comisión Económica para América Latina y el Caribe (CEPAL). https://repositorio.cepal.org/handle/11362/40456

Sutherland, A. (2018). Reinventing the rural: a new perspective on our countryside. The Architectural Review.

https://www.architectural-review.com/essays/reinventingthe-rural-a-new-perspective-on-our-countryside/10029195. article
Tambook. (2017). Plataforma digital de monitoreo del Programa Nacional de Tambos "Tambook".

http://www.pais.gob.pe/tambook/

Vidal, J. P. (2014). Las ocho regiones naturales del Perú. Terra Brasilis, (3). https://doi.org/10.4000/terrabrasilis.1027

Zavaleta, C. (2016). Impacto de corto plazo en población rural y rural dispersa. Ministerio de Vivienda, Construcción y Saneamiento (MVCS). http://www.pais.gob.pe/webpais/public/ publicaciones/estudio_impacto 